Analitika: Jurnal Magister Psikologi UMA, Vol. 12 (2) Desember (2020)

ISSN: 2085-6601 (Print), ISSN: 2502-4590 (Online)

DOI: http://doi.org/10.31289/analitika.v12i2.3704

\title{
ANALITIKA
}

Jurnal Magister Psikologi UMA

Available online http://ojs.uma.ac.id/index.php/analitika

\section{Perilaku Cyberbullying Remaja di Media Sosial}

\section{Youth Cyberbullying Behavior in Social Media}

\author{
Rahmiwati Marsinun \& Dody Riswanto* \\ Prodi Bimbingan dan Konseling, FKIP, Universitas Muhammadiyah Prof. Dr. Hamka, Indonesia \\ Prodi Bimbingan dan Konseling, FKIP, Universitas Mathla'ul Anwar Banten, Indonesia
}

Diterima: 26 April 2020, disetujui: 17 Desember 2020, dipublish: 30 Desember 2020

*Corresponding author: E-mail: ronaldody32@gmail.com

\begin{abstract}
Abstrak
Cyberbullying adalah tindakan negatif yang dilakukan oleh seseorang atau kelompok tertentu dengan cara mengirimkan pesan teks, foto, gambar meme, dan video ke akun media sosial seseorang dengan tujuan untuk menyindir, menghina, melecehkan, mendiskriminasi bahkan mempersekusi individu. Berdasarkan hasil data statistik, sebagian besar pelaku cyberbullying didominasi adalah remaja. Urgensi penelitian ini adalah cyberbullying merupakan fenomena yang sering terjadi di Indonesia dan telah menjadi gejala umum. Penelitian ini menggunakan metode kualitatif dengan teknik pengumpulan data seperti pengamatan atau observasi, studi dokumentasi, serta pengumpulan informasi audio visual. Analisis data dilakukan dengan teknik penarikan kesimpulan melalui kategorisasi, sintesis, penafsiran dan evaluasi yang menghasilkan makna deskriptif. Ringkasan hasil penelitian menunjukkan bahwa motif para remaja melakukan tindakan cyberbullying adalah: ketidaksukaan terhadap person atau pribadi seseorang, bermaksud menyindir dengan kalimat-kalimat negatif yang kurang etis dan kasar, bertujuan untuk menghibur agar para user atau pengguna internet dapat tertawa, perasaan dengki dan hasud yang menimpa diri remaja, dan merasa bahwa dirinya lebih baik dan berkualitas dibanding orang lain sehingga beranggapan bahwa tindakan cyberbullying adalah hal yang wajar. Penelitian ini dapat memberikan manfaat dan kontribusi bagi pengembangan ilmu psikologi dan konseling, khususnya pada pengembangan kognitif remaja serta pencegahan dan treatment yang harus dilakukan.
\end{abstract}

Kata kunci: Cyberbullying; Remaja; Media Sosial

\begin{abstract}
Cyberbullying is a negative action carried out by a person or a certain group by sending text messages, photos, meme pictures and videos to someone's social media account with the aim to insinuate, insult, harass, discriminate and even execute individuals. Based on the results of statistical data, the majority of cyberbullying perpetrators are predominantly adolescents. The urgency of this research is cyberbullying is a phenomenon that often occurs in Indonesia and has become a common symptom. This research uses qualitative methods with data collection techniques such as observation or observation, documentation study, and gathering audio visual information. Data analysis was performed with the technique of drawing conclusions through categorization, synthesis, interpretation and evaluation that produced descriptive meanings. The summary of research results shows that the motives of adolescents to commit cyberbullying are: dislike of someone or someone, intends to insinuate with negative sentences that are less ethical and abusive, aimed at entertaining so that users or internet users can laugh, envy and have befall adolescents, and feel that they are better and more qualified than others so that the act of cyberbullying is a natural thing. This research can provide benefits and contributions to the development of psychology and counseling, especially in adolescent cognitive development and prevention and treatment that must be done.
\end{abstract}

Keywords: Cyberbullying; Teenagers; Social Media.

How to Cite: Marsinun, R., \& Dody, R. (2020). Perilaku Cyberbullying Remaja di Media Sosial. Analitika: Jurnal Magister Psikologi UMA, 12 (2): 98 - 111 


\section{PENDAHULUAN}

Remaja merupakan periode kritis masa peralihan dari anak menjadi dewasa. Pada remaja terjadi perubahan hormonal, fisik, psikologis maupun sosial yang berlangsung secara sekuensial. Pada anak perempuan, pubertas terjadi pada usia 8 tahun sedangkan anak laki-laki terjadi pada usia 9 tahun. Faktor genetik, nutrisi, dan faktor lingkungan lainnya dianggap berperan pada tahap pubertas. Perubahan fisik yang terjadi pada periode pubertas ini juga diikuti oleh maturasi emosi dan psikis. Secara psikososial, pertumbuhan pada masa remaja (adolescent) dibagi dalam 3 tahap yaitu early, middle, dan late adolescent. Masing-masing tahapan memiliki karakteristik tersendiri. Segala sesuatu yang mengganggu proses maturasi fisik dan hormonal pada masa remaja ini dapat mempengaruhi perkembangan psikis dan emosi sehingga diperlukan pemahaman yang baik tentang proses perubahan yang terjadi pada remaja dari segala aspek (Batubara, 2016).

Perkembangan remaja apabila ditinjau dari sisi psikologis atau kematangan mental, maka dapat dilihat dari berbagai macam faktor, salah satu diantaranya adalah kemampuan remaja untuk berinteraksi dengan lingkungan sosial atau kelompok teman sebaya. Kemampuan berinteraksi inilah yang pada tahap berikutnya berkembang menjadi keterampilan berkomunikasi sosial.

Keterampilan komunikasi sosial remaja dengan kelompok pertemanan sebaya dilakukan atas dasar perwujudan terhadap identitas diri remaja yang ingin mendapatkan pengakuan dari kelompok pertemanan atau lingkungan sosial. Komunikasi yang berhasil adalah apabila komunikan (penerima pesan) merespon dengan baik pesan dari komunikator (pengirim pesan). Berdasarkan landasan tersebut, remaja yang memiliki kemampuan komunikasi baik cenderung diakui dalam suatu komunitas pergaulan serta eksis dalam kelompok pertemanan sebaya.

Diantara bentuk wujud komunikasi sosial para remaja adalah berkomunikasi melalui layanan internet, yang dikenal dengan media sosial atau social media. Data statistik dari APJII pada tahun 2019 menyebutkan terdapat sekitar 171 juta pengguna internet yang ada di Indonesia, pengguna internet sebagian besar berada pada usia produktif yaitu 15-19 tahun dan 20-24 tahun, dari 171 juta user atau pengguna tersebut, 150 juta user menggunakannya untuk mengakses media sosial.

Data statistik dari APJII menyimpulkan bahwa pengguna atau user internet di Indonesia didominasi oleh usiausia produktif, dan data menunjukkan usiausia remaja sebagian besar mengakses layanan internet untuk mengakses media sosial. Henri Kasyfi Sekjen APJII dalam media online IDN Times tahun 2018 menyimpulkan bahwa user atau pengguna internet di Indonesia sebagian besar hanya ditujukan untuk mengakses layanan chatting seperti Line, Whats app, We Chat dan lain-lain sebesar 89,35 persen, dan media sosial sebesar 87,13 persen untuk Facebook, Twitter, Instagram, dan beberapa akun media sosial yang lain.

Data statistik dari APJII menyimpulkan bahwa persentase pengguna internet di Indonesia sebagian besar didominasi oleh remaja, dengan memanfaatkan layanan internet hanya sebagai media percakapan atau chatting di 
media sosial, dan kurang memanfaatkan layanan internet sebagai sarana pembelajaran dengan mengakses informasi yang edukatif.

Dampak dari perilaku remaja yang hanya memanfaatkan layanan internet untuk chatting di media sosial, memiliki kecenderungan terhadap penyalahgunaan layanan media sosial tersebut, diantara bentuk penyimpangan penyalahgunaan layanan tersebut adalah Cyberbullying. Cyberbullying merupakan tindakan perundungan yang dilakukan oleh seseorang dengan menggunakan media internet, dengan berbasis pada situs atau platform jejaring sosial.

Definisi dari Cyberbullying yaitu tindakan mengintimidasi menggunakan media atau perangkat elektronik, tindakan perundungan di media sosial adalah tindakan yang disengaja oleh pelaku dengan maksud atau tujuan yang menyebabkan timbulnya kerugian, tindakan yang selalu dilakukan secara konsisten atau berulangulang, Cyberbullying selalu melibatkan suatu unsur hubungan yang ditandai dengan adanya ketidakseimbangan kekuatan (Hellsten, 2017). Cyberbullying adalah tindakan yang dilakukan oleh seseorang atau sekelompok orang terhadap individu lain melalui pesan teks, gambar/foto, atau video yang cenderung merendahkan dan melecehkan (Hidajat et al., 2015).

Kajian teori yang terangkum dalam beberapa literatur studi penelitian yang terdahulu, Penelitian di SDN 3 kotagede Yogyakarta, menunjukkan bahwa intensitas pengguna atau user media sosial berpengaruh positif dan juga signifikan terhadap adanya perilaku bullying siswa sekolah dasar kelas $\mathrm{V}$ dengan tingkat koefisien regresi sebesar 0,163 dan koefisien t hitung sebesar 6,646, dan pada taraf signifikansi 0,05 (Pratiwi, 2018).

Diantara bentuk - bentuk Cyberbullying atau perundungan adalah account facebook di-hack sampai disindir, dihina, dilecehkan di media sosial. Pada bentuk yang lain, account media sosial atau jejaring sosial seseorang diambil alih dan semua informasi bisa diganti-ganti tanpa sepengetahuan pemilik account (Utami, 2014).

Hasil temuan perundungan di Indonesia, ditemukan tiga objek perundungan siber atau Cyberbullying selain yang ada pada individu yaitu menyangkut wilayah, agama, dan institusi atau profesi tertentu(Rastati, 2016). Pengaruh Cyberbullying di media sosial berkontribusi terhadap perkembangan emosional remaja yaitu sebesar 31,36 persen dan 68,64 persen dipengaruhi oleh faktor yang lain (Setyawati, 2016). Penelitian di SMP Negeri 18 Makassar menemukan bahwa 32 persen siswa pernah melakukan tindakan bullying seperti mengejek, menjewer telinga, memalak, kemudian mempostingnya di internet (Aryani and Bakhtiar, 2018).

Tindakan cyberbullying pada media sosial facebook dipengaruhi oleh tiga hal yakni interaktivitas yakni seberapa besar proses interaksi diantara para pengguna facebook; konektivitas yakni berkaitan dengan kemampuan dan jangkuan akses diantara pengguna facebook. Keterangan dari responden remaja yang melakukan cyberbullying pada media facebook disampaikan melalui pesan-pesan yang bersifat verbal akan terasa kasar, vulgar dan terasa lebih menyakitkan dibandingkan dengan pesan yang disampaikan secara non verbal, karena cyberbullying yang disampaikan dalam bentuk non verbal dapat 
dikemas dalam bentuk gambar, meme dan simbol-simbol lainnya sehingga tidak akan begitu terasa pada orang yang menerimanya (Winoto, 2019).

Hasil penelitian di Yogyakarta tahun 2018 pada jejaring media sosial Instagram menunjukkan bahwa jenis cyberbullying yang dilakukan para remaja di Yogyakarta adalah 1) memberikan komentar yang kasar, 2) meng-update instastory, 3) meng-upload foto, dan 4) mengomentari foto, hasil penelitian juga menunjukkan perilaku cyberbullying remaja dipengaruhi oleh beberapa factor seperti 1) intensitas penggunaan media sosial, 2) kemampuan empati pelaku, 3) karakter dari korban (RizkyFitransyah \& Waliyanti, 2018).

Hasil penelitian di kota Padang pada tahun 2017 yang melibatkan 353 remaja awal (laki-laki 157 orang; perempuan 196 orang) dengan rentang usia responden antara 12 hingga 15 tahun menunjukkan bahwa jumlah korban perundungan maya di kalangan remaja awal hampir mencapai separuh dari responden, yaitu 172 responden (49\%). Itu artinya, hampir satu dari dua responden pernah menjadi korban peruundungan maya. Dari jumlah korban tersebut, terlihat bahwa jumlah remaja perempuan yang menjadi korban perundungan lebih banyak daripada lakilaki. Jumlah mereka adalah 99 responden (58\%), sedangkan korban yang berjenis kelamin laki-laki hanya 73 orang (44\%) (Sartana \& Afriyeni, 2017).

Hasil penelitian di kabupaten Semarang tahun 2017 menggambarkan cyberbullying pada remaja di SMAN 1 Ungaran dari jumlah total 286 subjek, sebanyak 206 (72\%) berada dalam kategori tinggi, 45 (16\%) subjek berada dalam kategori sedang, dan 35 (12\%) subjek dengan kategori rendah. Dari uraian tersebut dapat disimpulkan bahwa tingkat cyberbullying pada remaja di SMAN 1 Ungaran dalam kategori tinggi. Gambaran umum cyberbullying pada remaja di SMAN 2 Ungaran dari jumlah total 336 subjek, sebanyak 235 (70\%) berada dalam kategori tinggi, 71 (21\%) subjek berada dalam kategori sedang, dan 30 (9\%) subjek dengan kategori rendah. Dari uraian tersebut dapat disimpulkan bahwa kualitas cyberbullying pada remaja SMAN 2 Ungaran dalam kategori tinggi (Wiryada, Martiarini, Budiningsih, 2017).

Hasil penelitian tentang dampak cyberbullying terhadap depresi pada mahasiswa di STIKES Widya Husada Semarang tahun 2018, menunjukkan bahwa cyberbullying berdampak atau berkorelasi pada kejadian tingkat depresi pada mahasiswa dengan hasil p-value 0,02 $(<0,05)$ dan $r=0,273$ (Aini \& Apriana, 2019). Diantara faktor-faktor yang menyebabkan perilaku pelaku cyberbullying dalam melakukan aksinya, adalah faktor keluarga, diri sendiri dan lingkungan yang memiliki tingkat pengaruh cukup kuat dan signifikan. Analisis terhadap pengaruh perlindungan digital, perlindungan sosial dan faktor diri sendiri juga berpengaruh pada perilaku korban (Pandie \& Weismann, 2016).

Tujuan penelitian ini adalah mendeskripsikan motif-motif para pelaku cyberbullying di media sosial dan melihat dampak yang ditimbulkan dari para pelaku kepada target yang dijadikan korban ditinjau dari sudut pandang psikologis.

\section{METODE PENELITIAN}

Metode yang dipergunakan dalam kajian riset penelitian ilmiah ini yaitu 
melalui pendekatan kualitatif. Penelitian kualitatif adalah jenis riset yang hasil temuan-temuannya tidak diperoleh melalui prosedur statistik atau bentuk hitungan lainnya (Strauss \& Corbin, 2007). Lokasi penelitian berada di kabupaten Pandeglang Banten, subjek penelitian adalah para remaja pengguna layanan atau platform media sosial.

Rasionalisasi pemilihan wilayah Pandeglang sebagai lokasi penelitian adalah karena wilayah Pandeglang belum terjamah oleh para peneliti disebabkan faktor wilayah geografis yang jauh dan infrastruktur yang belum terbangun secara maksimal. Pandeglang dipilih karena wilayah ini adalah salah satu center atau pusat kebudayaan, sejarah, dan peradaban di provinsi Banten.

Peneliti berperan sebagai instrumen kunci dalam kajian riset ini. Kehadiran peneliti di lapangan melalui beberapa prosedur dan tahapan yaitu bagaimana pengamatan awal di lapangan terjadi, bagaimana cara menyesuaikan diri dengan lingkungan atau kondisi lapangan, serta menjalin hubungan atau keakraban yang baik dengan subjek yang harus diteliti (Riswanto et al., 2017). Peneliti harus hadir secara nyata di lapangan, tanpa bisa diwakilkan kepada orang lain, untuk melaksanakan observasi dan pengamatan tentang bagaimana proses kebudayaan yang berlangsung di lingkungan tersebut (Riswanto, 2017).

Teknik pengumpulan data diantaranya adalah pengamatan atau observasi, studi dokumentasi atau pencarian literature, serta informasi audio visual. peneliti kualitatif dapat menggunakan berbagai data-data yang vital yaitu wawancara, observasi, studi dokumentasi, serta informasi audio visual (Creswell, 2014).
Observasi dilaksanakan dengan prosedur memperpanjang pengamatan dengan memantau atau mengecek hasil percakapan para remaja di akun media sosial, studi dokumentasi dilakukan dengan teknik screenshot atau menduplikasi foto percakapan pada kolom komentar yang tersedia di media sosial, sedangkan informasi audio visual didapat melalui beberapa platform media sosial seperti Facebook, Instagram, dan Youtube.

Analisis data dilakukan dengan teknik menarik kesimpulan untuk menghasilkan pemaknaan yang bersifat deskriptif. Analisis data dalam kajian kualitatif melibatkan teknik pemilahan, pemeriksaan, evaluasi, kategorisasi, membuat sintesis, membandingkan, dan menafsirkan kode dan data serta menguji data mentah yang telah direkam (Neuman, 2014). Karakterisasi dari hasil akhir riset atau kajian kualitatif adalah menghasilkan koherensi yang bermakna (Tracy, 2013).

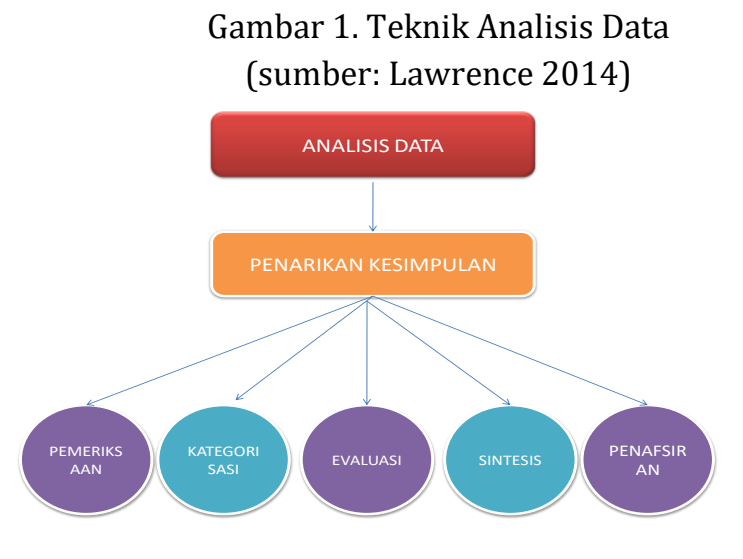

\section{HASIL DAN PEMBAHASAN}

Berdasarkan hasil dari observasi dan juga temuan peneliti, menemukan bahwa diantara bentuk-bentuk perundungan atau Cyberbullying adalah sindiran, ejekan, hinaan, caci maki, ancaman, pelecehan, diskriminasi, persekusi, ujaran kebencian, serta umpatan-umpatan negatif lainnya 
yang mengandung unsur sara, contohnya menyangkut tentang agama, kesukuan, golongan, ras, dan bentuk yang lainnya.

Perilaku Cyberbullying pada sebagian besar kasus diikuti dengan sindiran atau ejekan melalui foto atau gambar yang telah mengalami bentuk perubahan atau editing, yang dikenal dengan istilah meme, yang berwujud berupa foto atau gambar modifikasi yang selanjutnya diedit atau diubah sesuai dengan keinginan, dan pada tahap selanjutnya di-posting pada media sosial. dari meme tersebut selanjutnya mengundang reaksi para remaja untuk berkomentar atau memberi tanggapan pada kolom percakapan, yang selanjutnya diikuti dengan balasan berupa komentar-komentar negatif yang cenderung memberi sindiran atau melecehkan.

Hal ini sebagaimana pendapat dari beberapa ahli yang menyimpulkan bahwa perilaku perundungan atau Cyberbullying identik dengan komentar ataupun pesan yang cenderung melecehkan yang dilakukan secara berkala, terus menerus dan juga konsisten (Fauziah, 2016).

Jenis-jenis platform media sosial yang sering digunakan oleh para remaja sebagian besar diantaranya adalah Facebook, Twitter, dan Instagram, dan beberapa media sosial lain dengan jumlah pengguna yang sedikit, ketiga platform media sosial tersebut memiliki jumlah user atau pengguna yang sangat besar atau mayoritas, apabila dibandingkan dengan jenis media-media sosial yang lain.

Pada ketiga platform layanan media sosial tersebut tersedia fitur atau pilihan kolom komentar yang memungkinkan para user atau pengguna untuk saling berkomentar. Berdasarkan hasil temuan peneliti, situs layanan berbagi video seperti Youtube dapat dikategorikan sebagai media sosial yang berbasis video dikarenakan tersedianya kolom komentar bagi para user atau pengguna untuk menanggapi video yang telah ditonton.

Berdasarkan hasil observasi atau pengamatan peneliti, Cyberbullying dilakukan remaja dengan motif untuk menyindir atau menyerang personal atau pribadi seseorang, berupa komentarkomentar yang negatif berupa sindiran, ejekan, hinaan, caci maki, ketidaksetujuan, diskriminasi, persekusi, yang pada maksudnya adalah menyalahkan personal atau pribadi tersebut.

Bullying atau perundungan di media sosial ditunjukkan oleh para remaja atas dasar ketidaksukaan mereka terhadap personal atau pribadi seseorang, yang pada tahap permulaan memberikan komentarkomentar yang mengandung unsur humor atau candaan yang diharapkan dapat membuat user atau pengguna lain dapat tertawa dan turut memberikan tanggapan ataupun balasan pada kolom komentar dan pada tahap berikutnya saling membalas percakapan, tanpa disadari proses percakapan pada kolom komentar di media sosial tersebut masuk dalam ranah perundungan atau bullying walaupun sebenarnya para remaja menganggap hal itu sebagai unsur humor atau canda tawa belaka.

Berdasarkan hasil temuan peneliti, objek yang dapat dijadikan perundungan atau bullying oleh para remaja adalah mengenai kehidupan personal atau pribadi seseorang, misalnya mengenai mode atau cara berpakaian, body language atau bentuk tubuh seseorang, kepemilikan suatu barang, hubungan asmara seseorang, dan lain-lain. Ketidaksukaan terhadap kehidupan pribadi 
seseorang ini selanjutnya diwujudkan dengan ucapan atau kalimat-kalimat sindiran dan ejekan pada account media sosial yang dimiliki orang tersebut.

Sebagian besar para pemilik account media sosial tidak menanggapi sindiran atau kalimat-kalimat bernada bullying tersebut, namun pada sebagian kasus, pemilik account merasa jengkel karena para user atau pengguna dianggap terlalu berlebihan dalam memberikan komentar, maka pemilik account memilih untuk mengkonfrontasi pelaku dan mengambil tindakan tegas terhadap pelaku perundungan atau bullying tersebut, misalnya dengan cara menempuh jalur hukum.

Berdasarkan hasil atau pengamatan peneliti, contoh perilaku bullying misalnya pada mode berpakaian seseorang yang cenderung tidak disukai oleh remaja, sang pemilik account memfoto dan kemudian memposting mode berpakaiannya di media sosial, selanjutnya para remaja yang cenderung tidak menyukai mode atau cara berpakaian orang tersebut akan berkomentar 'nyinyir' atau negatif pada kolom komentar, makna kalimat yang diucapkan apabila dideskripsikan biasanya adalah 'ah cara berpakaiannya kuno alias ketinggalan zaman', 'padu padanan antara warna baju dan celana kurang pas gitu deh', 'terlalu ngejreng bro', 'bajumu kayak emakemak mau arisan', 'cara berpakaianmu mirip seorang pelacur', 'dandananmu persis seperti Waria alias bencong' dan komentarkomentar 'nyinyir' atau negatif lainnya.

Perilaku bullying atau perundungan lainnya adalah tentang body language atau bentuk tubuh seseorang, yang dikenal dengan istilah body shaming, sang pemilik account memfoto dirinya dan kemudian memposting gambar atau hasil foto selfie (kegiatan swafoto diri sendiri) di media sosial, dan selanjutnya para remaja berkomentar 'nyinyir' (mengulang-ngulang perintah, cerewet, menurut kamus KBBI) atau negatif pada kolom komentar, makna kalimat yang diucapkan apabila dideskripsikan biasanya adalah 'koq sekarang kurusan jeng', 'udah punya anak bayi badan semakin melar yaa', 'kurus kerempeng kayak mayat hidup', 'koq tambah gendutan sih sekarang', 'si badut sedang beraksi', si hidung pesek lagi selfie', dan beberapa komentar-komentar 'nyinyir' atau negatif lainnya yang tidak bisa disebutkan secara lengkap oleh peneliti.

Perilaku bullying atau perundungan lainnya adalah tentang kepemilikan suatu barang, yang sebagian besar berupa item aksesoris seperti tas, jam tangan, kalung, kacamata, dan lain-lain. Sang pemilik account memfoto kegiatan dirinya dan mempostingnya di media sosial, selanjutnya para remaja berkomentar 'nyinyir' atau negatif pada kolom komentar, makna kalimat yang diucapkan apabila dideskripsikan biasanya adalah 'itu tas kayaknya bukan kualitas original deh', 'pakai kalung imitasi aja sok-sok dipamerin', 'tas kw aja dibanggain', 'mana ada tes Hermes model kayak gitu, jangan-jangan tas kw alias palsu tuh', dan lain-lain yang pada intinya adalah bertujuan untuk menyindir secara negatif dan berusaha menunjukkan ketidaksukaan pelaku terhadap person atau pribadi seseorang yang dituding telah memakai barang-barang berkualitas $\mathrm{kw}$ atau palsu, bukan barang yang memiliki kualitas asli atau original.

Perilaku bullying atau perundungan lainnya adalah tentang kehidupan asmara seseorang, sebagian besar mengenai aktifitas keseharian keseharian pemilik 
account bersama pacar atau kekasih. Pemilik account memposting foto sedang bermesraan dengan pacar di media sosial, selanjutnya para remaja akan berkomentar 'nyinyir' atau negatif pada kolom komentar, makna kalimat yang diucapkan apabila dideskripsikan biasanya adalah 'dasar cewek matre', 'ternyata lu wanita simpanan om om yaa', 'selingkuhan bos-bos ternyata tu cewek', 'jangan munafik, dasar wanita pelakor', 'kamu itu ngga serasi ya punya pasangan bule, beda level', 'si buruk rupa pacaran sama bidadari' dan lain-lain, yang pada intinya menunjukkan ketidaksukaan pelaku terhadap kehidupan asmara pribadi seseorang.

Berdasarkan hasil observasi peneliti, perilaku bullying atau perundungan pada sebagian besar kasus biasanya diawali dengan foto seseorang yang mengalami proses editing fotografi. Selanjutnya foto tersebut ditulis dengan kalimat-kalimat 'nyinyir' atau sindiran serta hinaan, yang disebut dengan istilah meme, selanjutnya foto meme tersebut diposting di akun media sosial dengan tujuan untuk mendapatkan umpan balik atau feedback dari para user berupa komentar-komentar 'nyinyir' yang melihat foto meme tersebut.

Maksud para pelaku bullying awalnya ditujukan hanya sebagai media hiburan atau mengandung unsur humor belaka agar dapat menghibur para user atau pengguna internet, namun hal ini tidak berlaku bagi para korban meme tersebut, yang menganggap hal itu adalah suatu tindakan yang mengandung unsur pelecehan dan bersifat bullying. Kalimat-kalimat negatif bernada bullying di media sosial pada sebagian besar kasus pada awalnya memang hanya bertujuan sebagai humor yang bisa mengundang canda tawa diantara para user atau pengguna internet, namun pada beberapa kasus lainnya adalah bertujuan untuk menyerang personal atau pribadi seseorang, dengan melontarkan kalimatkalimat 'nyinyir' atau sindiran mulai dari yang halus sampai dengan yang kasar, kalimat berupa sindiran, ejekan dan diskriminasi, sampai bentuk ancaman atau persekusi yang ditujukan kepada pribadi tersebut.

Sebagian besar kasus menunjukkan bahwa pemilik account di media sosial merasa terganggu dengan adanya komentar-komentar 'nyinyir' atau negatif tersebut, yang pada akhirnya membuat beberapa pemilik account membuat keputusan untuk menutup kolom komentar di akun media sosial mereka.

Para remaja sering tidak memahami bahwa komentar-komentar 'nyinyir' atau negatif mereka di akun media sosial seseorang adalah masuk dalam ranah bullying, yang bisa dijerat ke pengadilan berdasarkan tindak unsur pidana, tentang pasal pencemaran nama baik, khususnya pasal undang-undang ITE.

Pelaku pencemaran nama baik seseorang di dunia maya atau media sosial dapat dipidanakan berdasarkan pasal 27 ayat 3 dan pasal 28 ayat 2 tentang undangundang nomor 19 pada tahun 2016 tentang perubahan atas undang-undang nomor 11 pada tahun 2008 tentang informasi dan transaksi elektronik berupa ancaman pidana penjara paling lama 4 tahun dan/atau membayar denda sebesar paling banyak 750 juta rupiah (Sitompul, 2018).

Hasil pengamatan peneliti, para remaja yang melakukan perundungan atau tindakan bullying di media sosial, awalnya hanya menganggap tindakan mereka 
sebatas pada aspek hiburan semata tanpa menyadari adanya konsekuensi hukum yang dapat dijerat secara hukum pidana berdasarkan pasal undang-undang ITE.

Bentuk-bentuk perundungan atau bullying yang dilakukan oleh para remaja diharapkan dapat membuat user atau pengguna internet bisa terhibur dan tertawa dari membaca komentar-komentar 'nyinyir' mereka, namun hal tersebut justru bisa mengundang user atau pengguna internet yang lain untuk saling membalas komentar 'nyinyir' atau negatif tersebut, yang pada akhirnya justru malah semakin menambah banyak para pelaku perundungan atau bullying di media sosial.

Dampak yang ditimbulkan dari tindakan perundungan atau bullying kepada para korban, biasanya berupa rasa emosional seperti tersinggung, marah, kesal, menangis, stress, depresi, perasaan bersalah, mengurung diri, merasa tidak berharga atau terdiskriminasi, menjauh dari pertemanan atau lingkungan sosial dan emosi-emosi negatif lainnya.

Pada beberapa kasus, korban bullying yang memiliki keberanian untuk menantang atau mengkonfrontasi para pelaku bullying, misalnya dengan cara mengajak para pelaku bertemu secara langsung atau hadir secara fisik, atau para korban yang menempuh jalur hukum dengan memilih untuk melaporkan para pelaku perundungan atau bullying pada pihak kepolisian, pada sebagian kasus yang lain, para korban yang tidak berdaya memilih untuk pasrah, menyimpan dendam, rasa trauma, serta terisolasi dari lingkungan sosial.

Beberapa hasil riset melakukan penelitian mengenai dampak Cyberbullying kepada para korban, diantaranya yaitu rentan mengalami kecemasan, depresi, prestasi di sekolah cenderung menurun, rasa ketidaknyamanan, enggan bergaul dengan kelompok teman-teman sebaya, berupaya untuk menghindar dari tekanan lingkungan sosial serta adanya upaya untuk melakukan bunuh diri (Rifauddin, 2016).

Tindakan verbal perundungan di media sosial memiliki pengaruh terhadap kondisi psikologi para korban, seperti mendapatkan ancaman, merasa tidak nyaman, merendahkan harga diri, takut dipenjara, curiga terhadap setiap orang yang menulis komentar, adanya intimidasi dari lingkungan sosial, dan membiasakan verbal perundungan sebagai sebuah percakapan biasa atau hanya sekedar lelucon. (Suciartini \&

Sumartini, 2018).

Pelaku bullying atau perundungan di media sosial seringkali tidak memikirkan dampak yang ditimbulkan akibat dari tindakan negatif yang mereka lakukan, hal ini disebabkan karena tingkat kepekaan masing-masing korban perundungan yang berbeda-beda. Sebagian korban bullying atau perundungan menganggap hal itu hanya sebatas bentuk humor atau tak lebih dari candaan saja, namun bagi beberapa korban bullying yang lain, hal itu merupakan tindakan pelecehan atau ejekan yang ditujukan kepada dirinya. Pelaku bullying atau perundungan mulai terlihat panik apabila korban mengambil tindakan terhadap komentar pelaku, yang berujung kerugian bagi pelaku bullying sendiri walaupun pada awalnya niat mereka hanya bertujuan untuk candaan atau humor belaka.

Berdasarkan hasil data kesimpulan dari jabaran diatas, peneliti merangkum hasil temuan jenis-jenis cyberbullying di 
media sosial yang termuat dalam diagram lingkaran di bawah ini:

\section{Diagram 1.}

Jenis-jenis Cyberbullying di Media Sosial

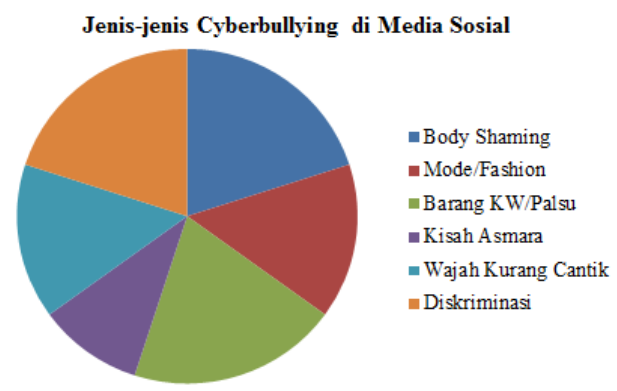

Berdasarkan hasil kumpulan dari literature data-data konkrit, fakta lapangan dan keterangan yang telah dirangkum, peneliti kemudian menganalisis motif-motif para pelaku terhadap tindakan perundungan atau bullying mereka di media sosial. Motif para remaja yang melakukan bullying atau perundungan dapat dikategorikan dalam beberapa fase, diantaranya adalah ketidaksukaan terhadap person atau pribadi seseorang, bermaksud untuk menyindir dengan kalimat-kalimat negatif yang tidak etis, bertujuan untuk menghibur agar para user atau pengguna internet tertawa, perasaan dengki dan hasud kepada korban, dan merasa dirinya lebih baik secara personal dibanding para korban. Motif pelaku bullying atau perundungan yang pertama adalah ketidaksukaan terhadap person atau pribadi seseorang. Ketidaksukaan pelaku ini bisa disebabkan oleh beberapa faktor, seperti korban yang memposting sesuatu di media sosial yang tidak sesuai dengan selera atau ekspektasi dari pelaku. Jadi korban harus memposting sesuatu di media sosial sesuai dengan selera atau ekspektasi dari pelaku bullying, apabila tidak sesuai dengan selera pelaku, maka komentar-komentar 'nyinyir' atau negatif yang akan korban dapatkan pada kolom komentar di akun media sosial.

Motif pelaku bullying atau perundungan yang kedua adalah bertujuan untuk menyindir dengan kalimat-kalimat negatif yang kurang etis, mulai dari sindiran secara halus sampai dengan sindiran secara kasar seperti komentar yang mengandung unsur pelecehan dan penghinaan. Motif ini disebabkan karena rasa dengki dan benci para pelaku terhadap para korban, dengan mengharapkan korban membaca tulisan mereka pada kolom komentar, maka terdapat unsur kesenangan dan kepuasan apabila pelaku telah berhasil untuk menyindir kehidupan pribadi seseorang.

Motif pelaku bullying atau perundungan yang ketiga adalah bermaksud hanya sebagai aspek hiburan semata agar dapat mengundang rasa tawa dari para user atau pengguna internet, dengan cara membuat gambar atau foto meme yang ditujukan kepada korban, maka diharapkan para user lainnya dapat menanggapi foto atau gambar meme tersebut dan saling membalas percakapan pada kolom komentar, namun tindakan yang kurang disadari oleh para pelaku adalah membuat gambar atau foto meme tersebut secara berlebihan sehingga kesan yang didapat adalah para korban merasa dilecehkan dan terintimidasi secara pribadi.

Motif pelaku bullying atau perundungan yang keempat adalah rasa dengki dan hasud yang menimpa pelaku, hal ini disebabkan karena korban memposting sesuatu di media sosial yang pada kehidupan nyata sulit dilakukan oleh para pelaku, sehingga rasa dengki dan hasud muncul kepada korban. Misalnya seperti remaja laki-laki yang memiliki kekasih atau pacar seorang gadis cantik, remaja laki-laki tersebut dinilai 
kurang layak memiliki kekasih seorang gadis cantik disebabkan memiliki fisik yang buruk rupa, cacat atau memiliki wajah yang kurang tampan, sehingga para pelaku merasa dengki dan hasud kepada korban, pelaku merasa lebih pantas dan layak mendapatkan kekasih tersebut dibanding korban, ketidakmampuan untuk meraih sesuatu yang diidamkan inilah yang melatarbelakangi tindakan bullying kepada para korban.

Motif pelaku bullying atau perundungan yang terakhir adalah merasa dirinya lebih baik dan pantas dibanding orang lain. Pelaku menilai korban bullying atau perundungan berada pada level yang tidak pantas atau kurang layak mendapatkan kenikmatan atau keuntungan, hal ini terjadi disebabkan para korban memposting sesuatu di media sosial seperti memiliki mobil mewah, meraih prestasi, berhasil dalam karir atau pekerjaan, memiliki kekasih yang cantik atau tampan, liburan ke luar negeri, dan lain-lain, pelaku merasa yakin bahwa secara kualitas maupun kuantitas kemampuan korban masih dibawah level dari para pelaku, sehingga mereka menilai bahwa para korban kurang layak dan tidak pantas untuk mendapatkan sesuatu tersebut yang selanjutnya diwujudkan dengan komentar-komentar 'nyinyir' atau bernada negatif akun media sosial.

Tindakan pencegahan yang harus dilakukan untuk mengurangi atau mereduksi perilaku bullying remaja di media sosial, contohnya seperti melakukan tindakan preventif, memberikan edukasi secara khusus, atau memberikan pengetahuan secara epidemiologis. Hasil penelitian Cyberbullying di negara Kroasia, bahwa langkah pertama yang harus dilakukan sebelum mengimplementasikan tindakan intervensi pencegahan yang bertujuan untuk mengurangi tindakan perundungan atau Cyberbullying di antara para pelajar adalah dengan melaksanakan pembelajaran berbasis epidemiologis.

Dengan melakukan studi epidemiologis tentang perundungan atau Cyberbullying pada tingkat sekolah dasar dan menengah, mereka mengumpulkan data yang teruji atau valid dan dapat digunakan untuk prevalensi Cyberbullying di negara Kroasia. Hal tersebut berdampak pada implementasi yang memungkinkan program pencegahan secara efektif yang bertujuan agar mengurangi prevalensi Cyberbullying diantara para pelajar (Capurso et al., 2017).

Langkah - langkah penanganan Cyberbullying di Indonesia sendiri termuat secara eksplisit dalam Undang-Undang Nomor 11 Tahun 2008 tentang Informasi dan Transaksi Elektronik sebagaimana telah diubah dengan Undang-Undang Nomor 19 Tahun 2016 tentang Perubahan atas Undang-Undang Nomor 11 Tahun 2008 tentang Informasi dan Transaksi Elektronik. Pada prinsipnya, tindakan menujukkan penghinaan terhadap orang lain tercermin dalam Pasal 27 ayat (3) UU ITE yang berbunyi:

"Setiap Orang dengan sengaja dan tanpa hak mendistribusikan dan/atau mentransmisikan dan/atau membuat dapat diaksesnya Informasi Elektronik dan/atau Dokumen Elektronik yang memiliki muatan penghinaan dan/atau pencemaran nama baik".

Adapun ancaman pidana bagi mereka yang memenuhi unsur dalam Pasal 27 ayat (3) UU 19/2016 adalah dipidana dengan pidana penjara paling lama 4 (empat) tahun dan/atau denda paling banyak Rp 750 juta (Pramesti, 2018). 
Diagram 2.

Data 150 Juta Pengguna Media Sosial di Indonesia

(Sumber: Katadata Statistik 2019)

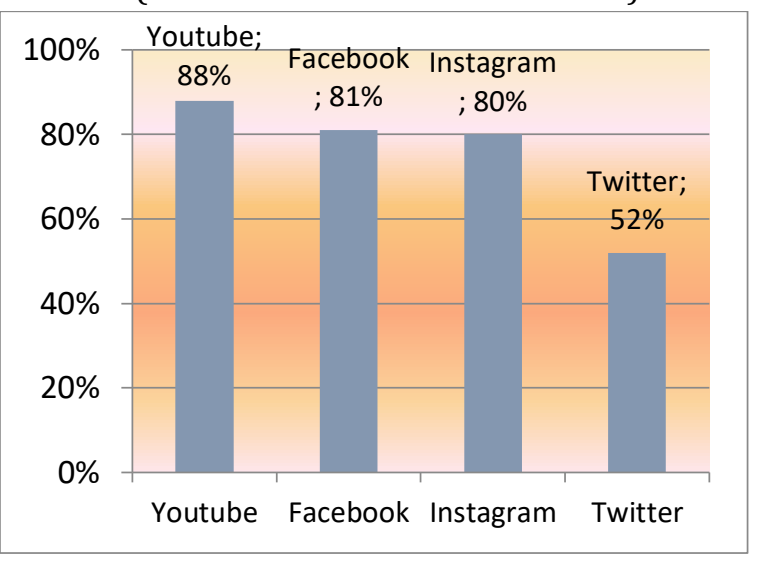

\section{SIMPULAN}

Cyberbullying adalah tindakan negatif yang dilakukan oleh individu atau kelompok-kelompok tertentu dengan cara mengirimkan message atau pesan teks, gambar atau foto meme serta video di media sosial yang mengandung unsur pelecehan, sindiran, hinaan, diskriminasi, dan persekusi kepada para korban bullying. Sebagian besar pelaku Cyberbullying atau perundungan didominasi oleh remaja, hal ini disebabkan pengguna internet terbesar di Indonesia adalah para remaja berdasarkan data statistik, karena itu kecenderungan untuk melakukan tindakan perundungan atau bullying di media sosial ada pada diri remaja.

Motif remaja dalam melakukan tindakan bullying di media sosial dapat dikategorikan sebagai berikut; (1) adanya ketidaksukaan terhadap person atau pribadi seseorang yang dinilai kurang pantas atau layak bagi para pelaku; (2) bertujuan untuk menyindir dengan kalimat-kalimat negatif atau tidak etis kepada para korban disebabkan rasa dengki dan hasud yang menimpa para pelaku; (3) bermaksud untuk menghibur agar dapat mengundang canda tawa dari para user atau pengguna internet seperti gambar atau foto meme yang diposting di account media sosial para korban; (4) terdapat perasaan dengki dan hasud yang menimpa pelaku disebabkan para korban bullying dinilai kurang pantas dan layak dalam meraih kesuksesan atau keberhasilan yang telah diperoleh; (5) pelaku merasa yakin bahwa dirinya lebih baik dan pantas dibanding para korban baik dari segi kualitas maupun kuantitas.

Penelitian ini berimplikasi pada sebuah rekonstruksi pemikiran bagi para pelaku cyberbullying di media sosial bahwa dampak atau efek jangka panjang yang diakibatkan dari perbuatan bullying bagi para korban dapat menimbulkan efek traumatis yang mendalam, seperti marah, kecewa, depresi, bahkan bunuh diri, karena itu untuk meminimalisir efek traumatis tersebut, para pelaku harus merubah sudut pandang atau cara berpikirnya dengan merekonstruksi pemikiran mereka secara menyeluruh agar dapat memposisikan diri dengan baik khususnya tentang konsep bullying di media sosial.

Saran yang ditujukan bagi para peneliti berikutnya adalah agar dapat melihat dampak atau efek psikologis dari cyberbullying di media sosial. Bahwa cyberbullying tidak dapat dianggap sepele, karena efek yang ditimbulkan sangat mengerikan pada remaja seperti depresi dan percobaan bunuh diri, karena itu disarankan pada peneliti berikutnya untuk melihat dampak-dampak psikologis tersebut pada diri remaja.

Penelitian ini direkomendasikan pada para guru, orang tua, psikolog, dan konselor untuk memantau kegiatan anak di media sosial secara ketat. Anak harus diberi edukasi dan pemahaman mengenai penyampaian pendapat di media sosial yang 
baik untuk mencegah tindakan bullying serta efek yang ditimbulkannya.

\section{DAFTAR PUSTAKA}

Aini, K., \& Apriana, R. (2019). DampakCyberbullying Terhadap Depresi Pada Mahasiswa Prodi Ners. Jurnal Keperawatan Jiwa, 6(2), 91. https://doi.org/10.26714/jkj.6.2.2018.91-97

Aryani and Bakhtiar. (2018). Effect of assertive training on cyber bullying behavior for students. Konselor, 7(2), 78-88. https://doi.org/10.24036/020187210294-0-0o

Batubara, J. R. (2016). Adolescent Development (Perkembangan Remaja). Sari Pediatri, 12(1), 21. https://doi.org/10.14238/sp12.1.2010.21-9

Capurso, S., Paradžik, L., \& Čale Mratović, M. (2017). Cyberbullying among children and adolescents - an overview on epidemiological studies and effective preventive programs. Kriminologija $\mathcal{E}$ Socijalna Integracija, 25(1), 127-137. https://doi.org/10.31299/ksi.25.1.5

Creswell, J. W. (2014). Research Design: Qualitative, Quantitative and Mixed Methods Approaches (Fourth Edi). Sage Publications, Inc.

Fauziah, N. (2016). Cyberbullying di Indonesia: analisis kasus Rizky Firdaus Wicaksana alias Uus. Makalah Non Seminar, 7.

Hellsten, L. M. (2017). An Introduction to Cyberbullying Outline: Methodological Issues in Researching Cyberbullying.

Hidajat, M., Adam, A. R., Danaparamita, M., \& Suhendrik, S. (2015). Dampak Media Sosial dalam Cyber Bullying. ComTech: Computer, Mathematics and Engineering Applications, 6(1), https://doi.org/10.21512/comtech.v6i1.2289

Neuman, W. . (2014). Social Research Methods: Qualitative and Quantitative ApproachesSeventh Edition (Seventh ed). Pearson Education limited.

Pandie, M. M., \& Weismann, I. T. J. (2016). Pengaruh Cyberbullying Di Media Sosial Terhadap Perilaku Reaktif Sebagai Pelaku Maupun Sebagai Korban Cyberbullying Pada Siswa Kristen SMP Nasional Makassar. Jurnal Jaffray, $\quad$ 14(1), 43-62. https://doi.org/10.25278/jj.v14i1.188.43-62

Pramesti, T. J. . (2018). Sanksi Bagi Pem-Bully di Media Sosial.

Pratiwi, N. (2018). Pengaruh intensitas penggunaan sosial media dan penerimaan teman sebaya terhadap perilaku bullying siswa kelas $\mathrm{V}$ Sekolah Dasar. Basic Education, 149-161. http://journal.student.uny.ac.id/ojs/ojs/inde x.php/pgsd/article/view/10597/10131
Rastati, R. (2016). Bentuk Perundungan Siber Di Media Sosial Dan Pencegahannya Bagi Korban Dan Pelaku. Jurnal Sosioteknologi, 15(2), 169-186. https://doi.org/10.5614/sostek.itbj.2016.15.02. 1

Rifauddin, M. (2016). Fenomena Cyberbullying pada Remaja (Studi Analisis Media Sosial Facebook). Khizanah Al-Hikmah : Jurnal Ilmu Perpustakaan, Informasi, Dan Kearsipan, 4(1), 35-44.

Riswanto. (2017). Karakteristik Pribadi Ideal Calon Konselor Berdasarkan teks Huma Betang Suku Dayak (Kajian Hermeneutika Gadamerian). Universitas Negeri Malang.

Riswanto, D., Mappiare-AT, A., \& Irtadji, M. (2017). Kompetensi Multikultural Konselor pada Kebudayaan Suku Dayak Kalimantan Tengah. JOMSIGN: Journal of Multicultural Studies in Guidance and Counseling, 1(2), 215. https://doi.org/10.17509/jomsign.vii2.8320

RizkyFitransyah, R. , \& Waliyanti, E. (2018). Perilaku Cyberbullying Dengan Media Instagram Pada Remaja Di Yogyakarta. Indonesian Journal of Nursing Practice, 2(1), 36-48. https://doi.org/10.18196/ijnp.2177

Sartana, \& Afriyeni, N. (2017). Perilaku Perundung Maya (Cyber Bullying) Pada Remaja Awal. Journal Psikologis Insight, 1(1), 25-39. https://ejournal.upi.edu/index.php/insight/a rticle/download/8442/5299

Setyawati, I. (2016). Pengaruh Cyberbullying di Media Sosial Ask.fm Terhadap Gangguan Emosi Remaja. Universitas Lampung.

Sitompul, J. (2018). Pencemaran Nama Baik di Media Sosial, Delik Biasa atau Aduan. https://m.hukumonline.com/klinik/detail/ul asan/lt52oaa5d4cedab/pencemaran-namabaik-di-media-sosial-delik-biasa-atau-aduan

Strauss \& Corbin. (2007). Dasar-dasar Penelitian Kualitatif: Tata Langkah dan Teknik-teknik Teoretisasi Data. Terjemahan Shodiq $\mathcal{E}$ Muttaqien. Pustaka Pelajar Offset.

Suciartini, N. N. A., \& Sumartini, N. L. U. (2018). Verbal Bullying dalam Media Sosial. Jurnal Pendidikan Bahasa Indonesia, 6(2), 152-171.

Tracy, S. (2013). Qualitative Research Methods: Collecting Evidence, Crafting Analysis, Communicating Impact. Wiley-Blackwell A John Wiley \& Sons, Ltd, Publications.

Utami. (2014). Cyberbullying di Kalangan Remaja: Studi Tentang Korban Cyberbullying di Kalangan Remaja. Universitas Airlangga.

Winoto, Y. (2019). Remaja Dan Pandangannya Terhadap Cyberbullying Pada Media Facebook. Commed: Jurnal Komunikasi Dan 
Rahmiwati Marsinun \& Dody Riswanto, Perilaku Cyberbullying Remaja di Media Sosial

Media, 3(2), 121. https://doi.org/10.33884/commed.v3i2.980

Wiryada, Martiarini, Budiningsih. (2017). Gambaran Cyberbullying Pada Remaja Pengguna Jejaring Sosial Di Sma Negeri 1 Dan Sma Negeri 2 Ungaran. Intuisi: Jurnal Psikologi Ilmiah, 9(1), 86-92. 